\title{
EHMTI-0382. A distal epidural blood patch relieves low CSF pressure headache
}

\author{
CJ Hung ${ }^{*}$, CC Wu \\ From 4th European Headache and Migraine Trust International Congress: EHMTIC 2014 \\ Copenhagen, Denmark. 18-21 September 2014
}

\begin{abstract}
Introduction
Low CSF pressure headache is a clinical syndrome that identifies patients who were previously headache-free and who develop a persistent headache over $24 \mathrm{~h}$, or just a few days. The diagnostic feature of low CSF pressure headache is that of worsening when upright and significant improvement on lying flat. Conservative treatment options include bed rest, abdominal binder, hydration, caffeine, and corticosteroids. If conservative treatment fails, epidural blood patching is often the next option.
\end{abstract}

\section{Aim}

Since the accumulation of CSF leakage spreads widely, the injection site for the epidural blood patch may be difficult to choose in the management of low CSF pressure headache. We prefer the distal approach for the epidural blood patch which will be demonstrated in the following case.

\section{Case report}

A 31-year-old man spontaneously developed orthostatic headaches for 2 weeks. The pachymeningeal enhancement of brain is noted with venous sinus engorgement in the images of brain MRI. Spinal MRI demonstrated CSF signals along bilateral C5-6, C6-7, C7-T1, T1-2, T8-9, T9-10, T10-11, and T11-12 neural foramens with epidural fluid accumulation from $\mathrm{C} 7$ to T12 compatible with CSF leakage. Conservative treatment with bed-rest, intravenous fluid infusion of $3000 \mathrm{ml} \mathrm{QD}$, nonsteroidal anti-inflammatory drugs, and caffeine failed. An epidural blood patch of $6 \mathrm{~mL}$ through $\mathrm{T} 10-11$ interspinous space resulted in immediate headache relief.

\section{Conclusion}

Some patients have spontaneous low CSF pressure headache, most often due to a cryptic CSF leak. Epidural

Anesthesiology, Taichung Veterans General Hospital, Taichung, Taiwan blood patch at distal part relieves headache by immediately compressing the dural sac and raising intrathecal pressure.

No conflict of interest.

Published: 18 September 2014

doi:10.1186/1129-2377-15-S1-J7

Cite this article as: Hung and Wu: EHMTI-0382. A distal epidural blood patch relieves low CSF pressure headache. The Journal of Headache and Pain 2014 15(Suppl 1):J7.

Submit your manuscript to a SpringerOpen ${ }^{\odot}$ journal and benefit from:

- Convenient online submission

- Rigorous peer review

- Immediate publication on acceptance

- Open access: articles freely available online

- High visibility within the field

- Retaining the copyright to your article

Submit your next manuscript at $\gg$ springeropen.com

\section{SpringerOpen ${ }^{\circ}$}

(c) 2014 Hung and Wu; licensee Springer. This is an Open Access article distributed under the terms of the Creative Commons Attribution License (http://creativecommons.org/licenses/by/2.0), which permits unrestricted use, distribution, and reproduction in any medium, provided the original work is properly cited. 